\title{
Becoming Lean: The Way towards Sustainability of Higher Educations Institutions
}

\author{
Gusman Nawanir ${ }^{1}$, Mohammed Binalialhajji', Kong Teong Lim², and Mohd \\ Hanafiah Ahmad ${ }^{1}$ \\ ${ }^{1}$ Faculty of Industrial Management, Universiti Malaysia Pahang, Lebuhraya Tun Razak, 26300 \\ Gambang, Pahang, Malaysia \\ ${ }^{2}$ School of Technology Management and Logistics, Universiti Utara Malaysia, 06010 Sintok, \\ Kedah, Malaysia
}

\section{Abstract}

Sustainability has become a significant issue in today's business world, including in the education sector. The objective of this cross-sectional study is to examine the implications of lean higher education (LHE) implementation on HEls sustainability performance. Data were collected from academicians at a technical university in

Corresponding Author:

Gusman Nawanir

gusman@ump.edu.my

Received: 5 August 2019

Accepted: 14 August 2019

Published: 18 August 2019

Publishing services provided by

Knowledge E

(c) Gusman Nawanir et al. This article is distributed under the terms of the

Attribution License, which

permits unrestricted use and redistribution provided that the original author and source are credited.

Selection and Peer-review under the responsibility of the FGIC2019 Conference Committee.

\section{G OPEN ACCESS}

Malaysia. The study found positive relationships between LHE and sustainability performance in terms of environmental, economic, institutional, and social. The finding implies that in order to be sustainable, a university could exert more efforts in implementing LHE practices. This study subsidized to the current literature through bridging the gap of the lacking investigations on the potentials of lean management in the context of HEls. The Malaysian HEls could gain benefits through providing alternative solutions and suggestions to improve their business process, moving towards achieving sustainability performance.

Keywords: Lean, Sustainability Performance, Higher Education Institutions, Malaysia

\section{Introduction}

In Malaysia, sustainable development (SD) initiatives had started while the launching of the new economic policy (NEP) in the 1970s (Government of Malaysia, 2017). Afterward, a new economic model (NEM) was launched in 2009 to pursuit SD pointing high incomes, inclusivity, and sustainability (Government of Malaysia, 2017). These targets are consistent with the 2030 agenda for SD incorporating economics, social, and environmental development. One of the preferred areas in the Malaysian SD goal is the education sector (Government of Malaysia, 2017), especially the HEls. As stated in the Education Blueprint (Higher Education) 2015-2025 (Ministry of Education Malaysia, 2015), one of the overriding national aspirations is to ensure financial sustainability. Nowadays, evidence indicated that HEls worldwide is facing some critical issues. As 
highlighted by Montgomery (2017) the issues include the reduction of financial support and resources from governments and donors, struggle against increasing tuition fees, increasing operational costs, low student retention and completion rates, as well as pressure to deliver provision to corroborate economic development. The issues become complicated as the HEls have a complex network of stakeholders, including students, faculty, parents, research sponsors, taxpayers, and other related educational institutions. At the same time, HEls also have multifaceted activities done by other institutions, besides some unique HEls activities. Among the activities are purchasing and procurement, financial assistance for students, immigration and visa operations, finance and related business activities, students admission, human resource-related activities, research and development, community service, and many more. These issues are also faced by HEls in Malaysia, especially when the Malaysian Ministry of Education had established a rule that inspires HEls to be independent and leverages their income by giving autonomy status to the institutions. These challenges demand a substantial commitment to embrace SD principles. Today, the sustainability agenda in the HEls sector in Malaysia constantly magnets attention, such as environmental protection agencies, NGOs, and HEls stakeholders. Albeit the agenda has been articulated into tactical policies, only a few HEls have been stirring toward sustainable institutions (Abd-Razak, Abdullah, Nor, Usman, \& Che-Ani, 2011). Hussin and Kunjuraman (2017) argued that the lack of understanding on the principles of sustainability within the HEls context may cause this phenomenon, besides the fact that the concept is new and still in its infancy. Even though some studies addressed the HEls sustainability issues, most of the studies emphasize limited dimensions of sustainability (i.e., environmental sustainability). For instances, Darus et al. (2009) and Kwami, Che-Ani, Tawil, Tahir, and Basri (2014) reported sustainable planning and strategy for Universiti Kebangsaan Malaysia (UKM). Zen and LatifSaleh (2013) deliberated the approach of institutionalizing HEls sustainability and sustainable energy management program in Universiti Technology Malaysia (UTM). The implementation strategies for energy sustainability in UTM were also proposed by Low, Abdul, and Weng (2012). In addition, Abd-Razak, Mustafa, Che-Ani, Abdullah, and MohdNor (2011) and Abdullah, Razman, and Muslim (2017) discussed the development, issues, and obstacles towards sustainable campus among four research universities in Malaysia (i.e., UKM, Universiti Sains Malaysia (USM), Universiti Malaya (UM), and Universiti Putra Malaysia (UPM)).

Leal Filho et al. (2018) included environmental, economic, social, and institutional sustainability issues as the significant challenges faced by the HEls in their operations. In 
the operations management perspective, one of the leading root causes of the issues is the existence of "waste" in their operations (Balzer, Brodke, \& Thomas Kizhakethalackal, 2015; Montgomery, 2017). In the context of lean management, the waste was commonly defined as non-value added activities in operations or activities. According to Womack, Jones, and Roos (1990), waste may include any activities that absorb resources but generates no value. In order to afford a more unobstructed view on the sustainable idea and to incorporate them into the education, lean practices could be employed by HEls in order to leverage its sustainability status and become more efficient and leaner in the way higher education operates. Even though some institutions have gained some benefits from its implementation, some institutions are currently facing issues related to its implementation. According to Montgomery (2017), the issues include lack of knowledge and experience on lean implementation, failure to recognize problems where lean is an appropriate approach to use, inappropriate practices and measures, inappropriate documentation, lack of standardization, lack of utilization of skills and talents, departmental politics, and lack of data-driven management system. Along with the issues highlighted in the literature, this study attempts to highlight the implementation of LHE practices in an HEI in Malaysia, quantify the level of its implementation, and investigate its impact on sustainability performance. The HEI in Malaysia is selected because the implementation of this principle has not well-explored besides a lack of investigations to inquiry the successful LHE implementation in the universities from the developing countries. Also, the implementation of lean and its potential effects on sustainability performance are potentially influenced by the national context (Phan \& Matsui, 2010). Therefore, it is essential to keep investigating various contexts in order to establish a strong understanding of the effect of lean on sustainability, besides adding new standpoint to the state-of-the-art literature. Also, this study could contribute significantly to HEls development in Malaysia. This paper starts with the introduction, followed by a review of the existing literature. Subsequently, research design and analysis results will be discussed. The subsequent section will present the research findings. Finally, this paper ends with implications, limitations, and suggestions for future studies. 


\section{Literature Review}

\subsection{Lean Higher Education (LHE) Practices}

Lean is a method of continuous improvement in a workplace, which was initiated in Toyota Manufacturing Corporation in the 1980s. Womack et al. (1990) highlighted that lean thinking is the never-ending conversion of waste into value from the customer's viewpoint. Lean is both a methodology and management thinking, using many methods and tools, expected to enhance quality and eliminate waste. Lean can mean "less," and at the same time, "more." Less in term of wastes, cost, design time, fewer suppliers per customer, and fewer organizational layers. Conversely, it can also mean more in terms of flexibility and capability, employee empowerment, effectiveness and efficiency, customer satisfaction, quality, competitiveness, and profitability (Clare \& Dennis, 2005b).

The topics of lean in the literature are broad. Nowadays, the philosophy of lean has been actively transferred to other sectors beyond the manufacturing sector, such as higher education, healthcare, pharmaceutical, tourism and hospitality, transportation, and distribution. Countless studies have addressed this philosophy to target waste elimination while leveraging organizational performance through maximizing values, understand work as a process, form a smooth flow, respond to pull and aim for perfection (Womack et al., 1990). As stated initially by Ohno (1988), there is seven cardinal waste, which lean aims to reduce. They are overproductions, inventory, defects, motions, overprocessing, waiting, and transportation. Afterward, Womack and Jones (2003) familiarized the underutilized human capital as an addition to the cardinal waste. Douglas, Antony, and Douglas (2015) converted the waste in the manufacturing context to HEls, as presented in Table 1. This study abbreviates the types of waste as TIMWOODS. These waste are endeavored to be reduced by the implementation of lean practices.

In the context of HEls, there is a growing number of academic literature, which are emerging in the area such as Cudney, Venuthurumilli, Materla, and Antony (2018), Douglas et al. (2015), Malmbrandt and Åhlström (2013), and Narayanamurthy, Gurumurthy, and Chockalingam (2017). Even though some research has acknowledged important practices of LHE, there was no single opinion among the researchers concerning the significance of the lean practices. The lack of agreement becomes a reason why practitioners and researchers presented diverse sets of elements to cover the lean principles. The elements varied extensively based on the background of the scholars. Through an extensive literature review, this present study identified, compiled, a regrouped the scrambled practices to become seven related practices of LHE. Table 2 presents the 
TABLE 1: Waste in HEls.

\begin{tabular}{|c|c|c|}
\hline Types of waste & Waste in HEls context & Examples in HEls \\
\hline Transportation & $\begin{array}{l}\text { The movement of materials (e.g., } \\
\text { papers, multiple approvals, and } \\
\text { hand-overs) }\end{array}$ & $\begin{array}{l}\text { Multiple endorsements for conference } \\
\text { attendance, moving paper, parts, and } \\
\text { materials around buildings and } \\
\text { between different departments }\end{array}$ \\
\hline Inventory & $\begin{array}{l}\text { More supply or materials than required. } \\
\text { Records and documents held longer } \\
\text { than usefully required }\end{array}$ & $\begin{array}{l}\text { Too many marketing brochures, } \\
\text { stationery, and other documents, } \\
\text { photocopies of lecture notes, storage } \\
\text { for all the above in offices or } \\
\text { stockrooms }\end{array}$ \\
\hline Motions & $\begin{array}{l}\text { The unnecessary movement of staff } \\
\text { and students. Departments scattered } \\
\text { across various campuses. }\end{array}$ & $\begin{array}{l}\text { Moving employees and students } \\
\text { between classrooms or from one } \\
\text { building to another }\end{array}$ \\
\hline Waiting & $\begin{array}{l}\text { Queuing for anything, waiting for } \\
\text { documents to be approved, IT systems } \\
\text { downtime, looking for files, books, and } \\
\text { documents. It includes the time taken } \\
\text { to respond to student queries }\end{array}$ & $\begin{array}{l}\text { Waiting for multimedia systems to start } \\
\text { up or classrooms to empty of previous } \\
\text { occupants, waiting for maintenance } \\
\text { technicians, waiting for approval, } \\
\text { searching for books, papers, handouts, } \\
\text { files, etc. }\end{array}$ \\
\hline Over-processing & $\begin{array}{l}\text { Overdesigning a product or a service. } \\
\text { Multiple approvals or handovers. } \\
\text { Multiple checks. A new program is } \\
\text { launched without having the } \\
\text { procedures ready to deliver }\end{array}$ & $\begin{array}{l}\text { Too much info through e-mail, too } \\
\text { many approvals required, and too many } \\
\text { people involved. Too many student } \\
\text { surveys and too many meetings }\end{array}$ \\
\hline Overproduction & $\begin{array}{l}\text { Producing more than what is needed. } \\
\text { Unbalanced workload across } \\
\text { semesters and uneven scheduling }\end{array}$ & $\begin{array}{l}\text { Too many teaching handouts made in } \\
\text { advance and then stored. The } \\
\text { workload is uneven across semesters } \\
\text { and timetabling of students is not level } \\
\text { across days or weeks }\end{array}$ \\
\hline Defect & $\begin{array}{l}\text { Errors in inputting data and } \\
\text { underutilized classrooms }\end{array}$ & $\begin{array}{l}\text { Wrong grades input into the system, } \\
\text { correcting, and checking data. } \\
\text { Timetabling errors }\end{array}$ \\
\hline Skills & $\begin{array}{l}\text { Not using people's full talent. Giving } \\
\text { people the wrong work }\end{array}$ & $\begin{array}{l}\text { Staff not teaching their specialist } \\
\text { subject area, not teaching } \\
\text { postgraduate courses, no research or } \\
\text { scholarly activity time }\end{array}$ \\
\hline
\end{tabular}

practices and the main focus of each practice. Several studies on the implementation of lean proposed the holistic implementation of all practices simultaneously because of the complementarity nature among the practices (Furlan, Vinelli, \& Dal Pont, 2011; Khanchanapong et al., 2014; Nawanir, Lim, Othman, \& Adeleke, 2018). In other words, the practices are unidimensional. This implies that the implementation of one practice may support the implementation of other practices. Based on these empirical supports, this study proposes the higher order model of LHE.

A couple of studies, such as Balzer et al. (2015) and Dinis-Carvalho and Fernandes (2017) signified the positive implications of the lean implementation on the HEls performance. For instances, Balzer et al. (2015) suggested the benefits of LHE implementation 
TABLE 2: Practices of LHE.

\begin{tabular}{l|l}
$\begin{array}{l}\text { Practices } \\
\text { Waste identification }\end{array}$ & $\begin{array}{l}\text { Main focus } \\
\text { Identifying waste (i.e., non-value added activities) through value stream } \\
\text { mapping of processes (Douglas et al., 2015; Hadid \& Mansouri, 2014; } \\
\text { Malmbrandt \& Åhlström, 2013). }\end{array}$ \\
$\begin{array}{l}\text { Work standardization } \\
\text { Whether or not there are standardized works and whether or not the } \\
\text { standards are formalized (Douglas et al., 2015; Malmbrandt \& Åhlström, } \\
\text { 2013). }\end{array}$ \\
$\begin{array}{l}\text { Level and balance } \\
\text { Proactive efforts in service to level and balance workloads as much as } \\
\text { possible (Douglas et al., 2015; Nawanir et al., 2018). }\end{array}$ \\
$\begin{array}{l}\text { Built-in quality } \\
\text { Whether the quality is built-in or not. It is essential to ensure that quality } \\
\text { is built-in from the start. Therefore, inspections and quality control are } \\
\text { less required. (Malmbrandt \& Åhlström, 2013). }\end{array}$ \\
$\begin{array}{l}\text { Focuses on the use of pull principles and the use of signal for starting an } \\
\text { activity (Malmbrandt \& Åhlström, 2013; Nawanir et al., 2018). }\end{array}$ \\
$\begin{array}{l}\text { Developing skills of employees in order to be multi-skilled and } \\
\text { multi-functional (Nawanir et al., 2018). }\end{array}$ \\
$\begin{array}{l}\text { Continuous improvement activities, employee participation in } \\
\text { improvement agenda, improvement work, problem-solving, and } \\
\text { employees }\end{array}$ \\
$\begin{array}{l}\text { improvements (Balzer et al., 2015; Thomas, Antony, Francis, \& Fisher, } \\
\text { improvement }\end{array}$
\end{tabular}

among universities in the US by highlighting its positive impacts on waste elimination besides also highlighting the reduction in operational costs of the HEls after the lean implementation. The next sections of this paper will highlight the potential effects of LHE on the sustainability of HEls.

\subsection{Sustainability in HEls}

Over the most recent couple of years, some crucial investigations have been led on HEls' engagement in executing SD agenda (Aleixo, Ulisses, \& Susana, 2018a; Cebrián, Grace, \& Humphris, 2015; Dyer \& Dyer, 2017). There are the same cases of SD in various dimensions around the world and incorporated in the main activities of HEls (Aleixo et al., 2018a; Fischer, Jenssen, \& Tappeser, 2015). With regards to the sustainability of HEls; while few researchers assert that SD has been applied in all HEl system (Lozano, 2011), it is perceived that a comprehensive approach has not been taken in light of the fact that activities have been classified and applied in just a single or two dimensions of the education system (Aleixo et al., 2018a; Lozano et al., 2015). Three pillars of SD have been recognized in the literature (Amaral Luís, Martins Nelson, \& Gouveia Joaquim, 2015; Godemann, Bebbington, Herzig, \& Moon, 2014) including environmental, social and economic sustainability. However, it is currently common to discover other SD dimensions, remarkably institutional (Aleixo et al., 2018a; Lozano, 2011; Lozano et al., 
2015) and cultural (Lozano et al., 2015). At the same time, four measurements of SD have additionally been proposed for the execution of SD in HEls (Aleixo et al., 2018a; Lozano et al., 2015), specifically, economic, environmental, institutional/educational/political, and social/cultural (Aleixo et al., 2018a).

\subsubsection{Economic sustainability}

Economic sustainability refers to the sustain, safeguard, and use of resources (material and human) to generate long-range sustainable values by best recovery, use, and recycling. In other words, conserving natural resources today to ensure the forthcoming generations can fulfill their needs. The economic measurement of SD includes economic viability and classifies economic needs, for example, focus about plans to get better budget for practices encouraging SD, energy efficiency and economic performance (Aleixo et al., 2018a; Lozano, 2011). Several studies, such as Henao, Sarache, and Gómez (2018), Iranmanesh, Zailani, Hyun, Ali, and Kim (2019) and Hussain, Al-Aomar, and Melhem (2019), noted the significant positive effect of lean on economic performance indicators (e.g., profitability, profit margin, and return on investment). Also, the studies (Hines, Found, Griffiths, \& Harrison, 2011; Moyano-Fuentes \& Sacristán-Díaz, 2012) reported that the concept of lean positively affects economic sustainability performance. This clues the following hypothesis:

Hypothesis 1. LHE positively affects economic sustainability performance.

\subsubsection{Environmental sustainability}

Environmental sustainability is related to the issues about energy (petrol, electricity, solar, gas, oil, thermal, wind, and coal), transport, biodiversity (fauna and flora), water, resources like paper, computers, and ink (to eliminate their usage and their dumping as waste/pollution) and other packaging and resources being aware consumer (Aleixo et al., 2018a; Cathryn \& Deborah, 2008). The environmental measurement suggests the combination of environmental with organizational strategies. For example, the construction of sustainable infrastructure on campus, sorting of waste, and its procedures for equipment and recycling to create renewable energy (Aleixo et al., 2018a; Lozano, 2011). Recent literature provided strong support on the significant impact of lean on environmental performance. Piercy and Rich (2015) and Iranmanesh et al. (2019) stated that lean met multiple sustainability consequences including environmental benefits in 
terms of reduction on pollution, reduction on energy consumption while increasing the efficiency of energy usage. Other studies (Florida, 1996; King \& Lenox, 2001; Moreira, Alves, \& Sousa, 2010) agreed that the concept of lean affects environmental sustainability performance. This evidence leads to the following hypothesis:

Hypothesis 2. LHE positively affects environmental sustainability performance.

\subsubsection{Institutional, educational and political sustainability}

Institutional sustainability is associated with the execution of sustainability policies and simplification of making decisions (Pfahl, 2005). Moreover, it is about how organizations frame their values and strategy, and how diverse stakeholders sense the strategy to meet goals of SD (Lozano, 2011). The institutional sustainability also covers transparency in governance and ethical commitments of organizations (Piercy \& Rich, 2015), besides organizational declarations and partnership to promote the SD (Aleixo, Azeiteiro, \& Leal, 2018b). Literature included several factors to indicate this SD element, such as several types of research, training, publications, and collaborations related to campus sustainability. Looking at the LHE, it gives the impression that the LHE practices, such as value maximization, stakeholder involvement, and continuous improvement, could positively improve the institutional sustainability performance. Therefore, the following is hypothesized:

Hypothesis 3. LHE positively affects institutional sustainability performance.

\subsubsection{Social and culture sustainability}

Social sustainability focuses on generating successful sustainable places that encourage luxury by considering what people required from their workplaces (Scott, 2009). Social sustainability consists of corporate social responsibility (CSR) and the cases surrounding the welfare of students and staff such as safety, and workplace health, ethics, interconnectedness, inclusive community, partnerships, quality of life, integrity, respect, along with the capability to perform tasks in teams as the chance to understand and listen other's viewpoints (Aleixo et al., 2018a; Scott, 2009). It also assigns to activities either by the surrounding community or an organization's human resources for example, policies encouraging diversity and equality, participating and developing in cultural, recreational, or sports activities, initiatives and concerns for social inclusion, and scientific or cultural initiatives address the outside community (Aleixo et al., 2018a; Lozano, 
2011). Also, according to Aleixo et al. (2018a), this sustainability element is associated with rules and activities regarding the labor practices and decent work, quality of life, work health and safety, training, and participation in social activities. From a systems perspective, according to Piercy and Rich (2015), lean provides social-foundation for sustainability and pairs it with a technical-system to implement improvement. Also, several studies (Mason-Jones, Naylor, \& Towill, 2000; Moreira et al., 2010) agreed that the concept of lean affects social sustainability performance. Therefore, the following hypothesis is posited.

Hypothesis 4. LHE positively affects social sustainability performance.

\section{Methodology}

This cross-sectional study applied a quantitative design. The measurements for each indicator were adapted and adopted from several recent works of literature on lean management, and sustainable development as depicted in Appendix A. Data were collected by using a set of the close-ended survey with ordered choice questions ranging from 1 (strongly disagree) to 6 (strongly agree). In order to diminish the effect of temporary variations of the variables, the sustainability indicators were measured based on the attainments throughout the previous three years. Content validity, reliability, and brevity of the instrument were assured by relying on the judgment from experts consisting of academicians and practitioners in the area of lean and sustainability. Three hundred questionnaires were self-administered to the respondents, with 102 questionnaires were returned. However, 14 questionnaires were discarded from the analysis because of incomplete answers and outliers. Finally, 88 questionnaires were completed and usable for further analysis, with an effective response rate of $29.33 \%$. Based on the usable responses, 43 (48.86\%) of the participants were senior lecturers, 38 (43.18\%) lecturers, and 7 (7.95\%) associate professors. Based on their working experience, majority of the respondents (88.64\%) have been working in the institution for more than five years, and $11.36 \%$ served the university for between three and five years. Based on these figures, the respondents were sufficiently knowledgeable to participate in the survey. Structural Equation Modeling (SEM) approach with SmartPLS 3.2.8 software were used to analyze the data because besides it can perform simultaneous estimation of all parameters in a model (lacobucci, Saldanha, \& Deng, 2007), it provides more comprehensive evidence about the extent to which the model is supported by data (Hair, Hult, Ringle, \& Sarstedt, 
2017; Latan et al., 2018). More importantly, the PLS-SEM provides a robust estimation for non-normal data and small sample size (Hair Jr, Hult, Ringle, \& Sarstedt, 2016).

\section{Results}

\subsection{Construct Validity}

Construct validity confirms that a set of manifest variables represents the latent variable that is proposed to measure (Hair Jr et al., 2016). Convergent validity characterized by outer loading, average variance extracted (AVE), and composite reliability (CR) was assessed. The details of the convergent validity are depicted in Appendix A. It shows that all outer loadings are higher than 0.50, AVE values are more than 0.50, and CR values are above 0.70 . Besides, as this study proposed a second-order model, the convergent validity of the $2^{\text {nd }}$ order construct was also assessed. The assessment on the secondorder model shows that outer loadings ranged from 0.713 to $0.880, A V E$ is 0.660 , and CR is 0.930 . Therefore, the convergent validity of both first and second-order constructs are satisfactory. Furthermore, discriminant validity was also measured to reflect the extent to which each of the constructs is unique and not redundant with other constructs (Hair Jr et al., 2016). The discriminant validity was examined by using the Heterotrait-Monotrait ratio of the correlations (HTMT) reflecting the average of the heterotrait-heteromethod correlations relative to the average of the monotrait-heteromethod correlations (Hair Jr et al., 2016). Table 3 shows the results of HTMT assessment indicating the sufficient discriminant validity with the highest HTMT values of 0.871 , which is below the threshold value of 0.90 (Gold, Malhotra, \& Segars, 2001). In a nutshell, the measurement model provided a satisfactory construct validity.

TABLE 3: Discriminant validity: Heterotrait-monotrait Ratio Statistics (HTMT).

\begin{tabular}{cccccccccccc}
\hline & BINQ & CIMP & ECSP & ENSP & ISP & LBW & MFE & PULL & SSP & WID & WSTD \\
\hline BINQ & & & & & & & & & & & \\
CIMP & 0.741 & & & & & & & & & & \\
ECSP & 0.537 & 0.754 & & & & & & & & & \\
ENSP & 0.619 & 0.390 & 0.584 & & & & & & & & \\
ISP & 0.690 & 0.736 & 0.871 & 0.594 & & & & & & & \\
LBW & 0.671 & 0.663 & 0.652 & 0.528 & 0.619 & & & & & & \\
MFE & 0.868 & 0.866 & 0.675 & 0.590 & 0.729 & 0.697 & & & & & \\
PULL & 0.828 & 0.660 & 0.629 & 0.644 & 0.733 & 0.579 & 0.647 & & & & \\
SSP & 0.733 & 0.787 & 0.760 & 0.606 & 0.868 & 0.663 & 0.803 & 0.736 & & & \\
WID & 0.520 & 0.435 & 0.477 & 0.442 & 0.523 & 0.505 & 0.379 & 0.671 & 0.559 & & \\
WSTD & 0.701 & 0.652 & 0.576 & 0.629 & 0.640 & 0.715 & 0.652 & 0.779 & 0.699 & 0.692 &
\end{tabular}


Note: BINQ = Built-in Quality; CIMP = Continuous Improvement; ECSP = Economic sustainability performance; ENSP = Environmental sustainability performance; ISP = Institutional sustainability performance; LBW = Level and Balance Workload; MFE = Multifunctional Employees; PULL = Pull System; SSP = Social Sustainability Performance; WID = Waste Identification; WSTD = Work Standardization.

\subsection{Structural Model Assessment: Hypothesis Testing}

The hypothesized path model is presented in Figure 1. This study hypothesized that the implementation of LHE practices positively affects sustainability performance indicators (i.e., economic, environmental, institutional, and social sustainability performance). The PLS bootstrapping based on 5000 bootstrap samples to derive a 95 percent biascorrected confidence interval was applied to test the hypotheses (Preacher \& Kelley, 2011). Table 4 shows that all the standardized beta values relating to the LHE and dependent variables are significant at $p<0.05$ ( $t>1.645$ ) with non-zero confidence intervals. As the intervals are zero free, the positive relationships between LHE and all the sustainability performance indicators (economic, environmental, institutional, and social sustainability performance) are tenable. Therefore, all the hypotheses are supported.

TABLE 4: Summary of Hypotheses Testing.

\begin{tabular}{l|c|c|c|c|c|c|c|c|c|c|c|}
$\begin{array}{l}\text { Hypo- } \\
\text { theses }\end{array}$ & Path & $\begin{array}{c}\text { Std. } \\
\text { Beta }\end{array}$ & $\begin{array}{c}\text { Std. } \\
\text { Error }\end{array}$ & t-value & Bias & Confidence Interval & $R^{2}$ & $Q^{2}$ & Decision \\
\hline H1 & LHU $\rightarrow$ ECSP & 0.698 & 0.068 & 10.297 & -0.007 & 0.571 & 0.793 & 0.488 & 0.374 & Supported \\
H2 & LHU $\rightarrow$ ENSP & 0.622 & 0.091 & 6.824 & -0.005 & 0.440 & 0.740 & 0.387 & 0.257 & Supported \\
H3 & LHU $\rightarrow$ ISP & 0.766 & 0.055 & 13.928 & -0.003 & 0.657 & 0.839 & 0.587 & 0.426 & Supported \\
H4 & LHU $\rightarrow$ SSP & 0.807 & 0.044 & 18.349 & -0.001 & 0.714 & 0.859 & 0.650 & 0.458 & Supported \\
Note: $\mathrm{p}<0.05$ (1 tailed test) & & & & & & & & &
\end{tabular}

$R^{2}$ values indicating the coefficient of determinations were used to assess the amount of explained variance in the endogenous constructs. According to Hair Jr et al. (2016), the $\mathrm{R}^{2}$ values of $0.25,0.50$, and 0.75 for targeted constructs are considered weak, moderate, and substantial, respectively. Table 4 shows the $\mathrm{R}^{2}$ values for all endogenous latent variables in the hypothesized model. Based on the table, there is a medium effect of LHE on economic sustainability performance with $R^{2}=0.488$, which indicates that LHE explains $48.80 \%$ of the total variances in economic sustainability performance. Also, the LHE explains $38.70 \%, 58.7 \%$, and $65 \%$ of the total variances in the environmental, 


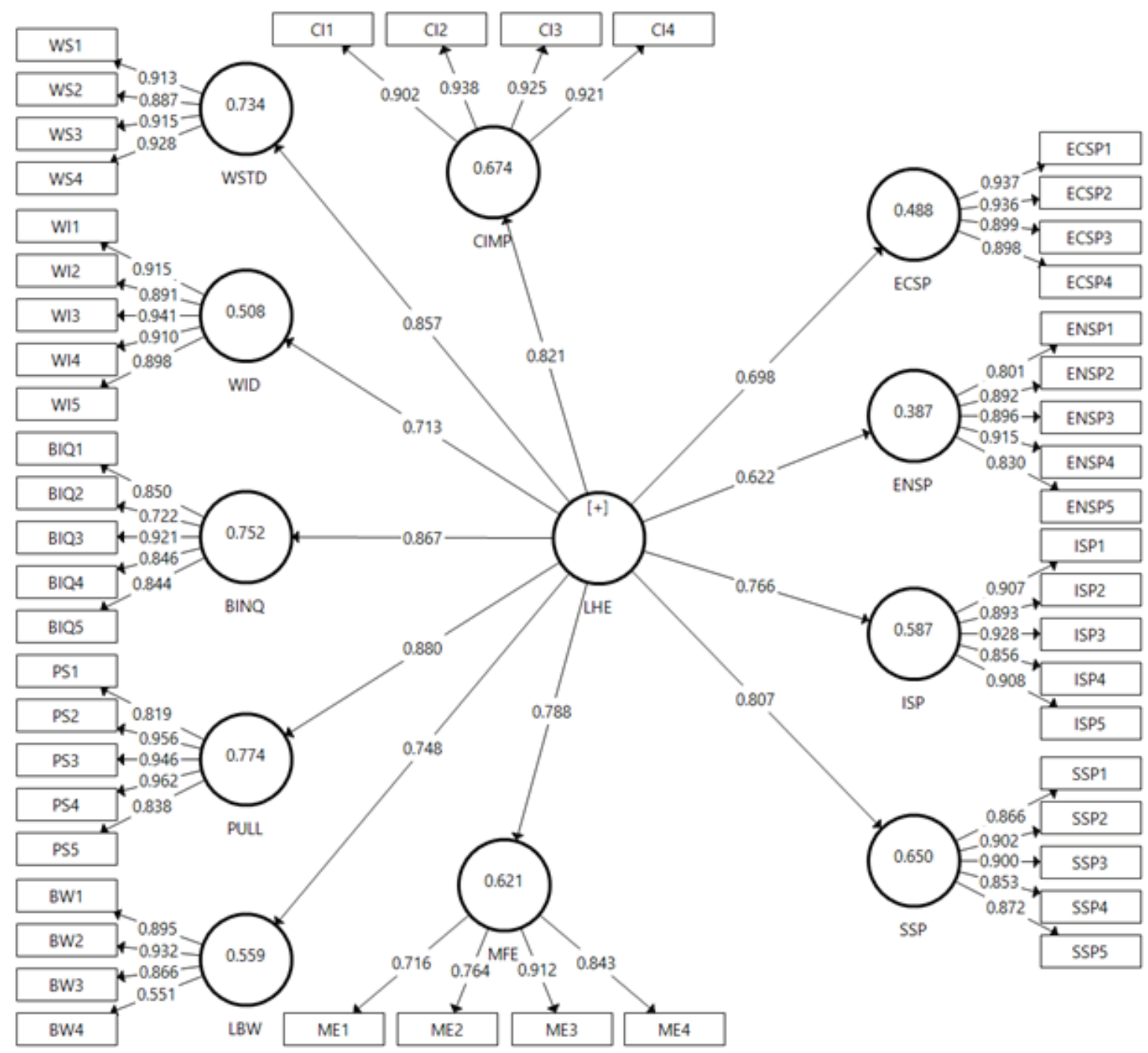

Figure 1: Hypothesized PLS Path Model.

institutional, and social sustainability performance, respectively. Hence the effects of LHE on economic and environmental performance are medium, whereas its effects on institutional and social performance are substantial. Also, a blindfolding was applied to ensure the predictive relevance $\left(Q^{2}\right)$ of the model. The $Q^{2}$ shows the ability of a model in predicting endogenous variables. The results were obtained through the variable score from which cross-validated redundancy is extracted. $Q^{2}$ shows the relevance of $0.374,0.257,0.426$, and 0.446 , respectively, for economic, environmental, institutional, and social sustainability performance. As the $Q^{2}$ values in all the endogenous variables are more than zero, the model has a predictive relevance (Hair et al., 2017). 


\section{Discussion}

This study was aimed at empirically investigating the effects of LHE on sustainability performance indicators. Four hypotheses relating LHE with each sustainability performance indicators (i.e., economic, environment, institutional, social) were tested by using PLS-SEM approach. The significant relationship between LHE and economic performance was proven with a confidence interval ranging between 0.571 and 0.793 and the estimated path coefficient $\beta$-value of 0.698 . Based on the derived results, LHE practices were verified to be able to contribute to economic sustainability performance positively. Thus, it implies that in order to enhance economic sustainability performance, the universities could exert more efforts on implementing LHE practices. The respondents believed that LHE practices might increase the university's overall financial performance, return on investment, and energy efficiency while reducing the university's operational costs. The outcome of the present study provides further confirmation of previous studies (Hines et al., 2011; Martínez-Jurado \& Moyano-Fuentes, 2014; MoyanoFuentes \& Sacristán-Díaz, 2012), which agreed that the concept of LHE has a positive effect on economic sustainability performance as they highlight the factors that clarify the sustained operational and financial consequences from the lean operation in the medium- and long-range.

The significant positive relationship between LHE and environmental sustainability performance was supported with the confidence interval ranging between 0.440 and 0.740 , and the estimated path coefficient of 0.622 . This result provides evidence that the employment of LHE contributes significantly to the achievement of environmental performance. It infers that to improve environmental sustainability performance, the universities should extensively apply LHE practices. The respondents believed that LHE practices lead to the use of energy-efficient equipment, tools, and machines; while reducing the consumptions of water, electricity, and fuel, besides the significant reduction in solid waste. This is because the main objective of LHE is to eliminate all types of waste in HEls. This indicates that respondents believe that LHE practices could assist in increasing the university environmental performance and leading it to be more notable. The outcome of the present study confirms some of the previous studies, such as those of Florida (1996), King and Lenox (2001), and Moreira et al. (2010). These authors agreed that the concept of LHE positively affects environmental sustainability performance, as according to them that lean practices found to be inherently capable of facilitating the attainment of environmental objectives and enhancements in environmental outcomes. 
Moreover, the study also found the significant relationship between LHE and institutional sustainability performance, with a path coefficient value of 0.766 and confidence interval ranging between 0.657 and 0.839 . This finding implies that LHE practices are proven to be able to contribute positively to institutional sustainability performance. It implies that there is a simultaneous contribution of LHE practices to heighten institutional performance. The respondents tend to agree that the implementation of LHE may enhance the awareness and understanding among the HEls stakeholders regarding the sustainable development-related issues. Also, this finding clues that LHE improve awareness among the stakeholders regarding the institutions' values as well as affect the way how the stakeholders perceived the visions, missions, values, and objectives of the institution (Aleixo et al., 2018a). Specifically, the number of researches to promote campus sustainability could be increased, besides the increase in the number of research and development projects related to the university's sustainable development, and participation of stakeholders in on-campus sustainable development activities.

Finally, the positive effect of LHE on social sustainability performance was supported with a confidence interval ranging between 0.714 and 0.859 and the estimated path coefficient of 0.807 . The analysis revealed that LHE practices synergistically improve social sustainability performance. This suggested that the respondents believe that the implementation of LHE practices could encourage the outstanding application of HRM principles in universities, outstanding support service, excellent occupational health service, impactful CSR, and beneficial recreational, cultural or sports activities. Meaning to say, the respondents believe that LHE practices could assist the improvement of the overall social sustainability performance and driving it to be more outstanding. The outcome of the present study supports some previous studies, such as Mason-Jones et al. (2000), Moreira et al. (2010), and Womack et al. (1990) which agreed that the concept of lean affects social sustainability performance. According to Moreira et al. (2010), it is insufficient for institutions to achieve their performance; they must also manage their business conscientiously, and to be aware of the impact of their activities on society.

\section{Conclusion and Implications}

To conclude, this study provided empirical evidence that LHE practices contribute positively to sustainability performance in term of economic, environmental, institutional, and social. It implies that to enhance sustainability performance, the HEls could exert more 
efforts on implementing LHE practices within the institutions. This study contributes to the body of knowledge in bridging the gap of the lack of study in the HEls context focusing on the effect of LHE towards sustainability performance in term of economic, environment, institutional and social as it is considered a new idea, especially in the Malaysian HEls. This paper also contributes to the practitioners, such as policymakers of HEls through providing the areas that enable them to survive and thrive and to decide whether to invest in these areas or not (Doman Mark, 2011). More importantly, this study is potential to contribute by providing the causes of the high operating costs, which are found to be wasted while proposing the methods that enable HEls to eliminate the waste and reduce the operating costs.

\section{Limitation and Suggestion for Future Research}

While this study provides several contributions practically and theoretically, some limitations should be highlighted, which in turn may provide opportunities for upcoming studies. The first limitation is related to the context of the study, which focused on a single technical university in Malaysia. Even though the data were collected from different faculties and centers, the implementations of LHE concepts in each faculty and center closely resemble with each other as they are still under the same umbrella. The future studies should focus on multiple institutions, which can provide a more unobstructed view related to LHE implementation and its implications on the sustainability of Malaysian HEls. Second, the sample of this study consisted of 88 academicians from a university, which could be considered small. Even though the data were analyzed by using SmartPLS, which is robust and effectively able to address the issue of sample size, future study should consider larger sample size, which will help to generate more convincing results. Third, this study is a cross-sectional study in which the data were collected once and represented at one point in time. As discussed in the literature, lean management is a long-term initiative and requires a long-term commitment (Vamsi Krishna Jasti \& Kodali, 2014), and their benefits sometimes cannot be realized in the short term. Given that, the effect of lean university principles on economic, environmental, institutional, and social sustainability performance can be analyzed relative to the time of their implementations. In other words, a longitudinal study would be essential to accurately examine how LHE principles leverage the institutions' sustainability. 


\section{Acknowledgment}

We want to thank Faculty of Industrial Management and FIM's Governance and Integrity Centre, Universiti Malaysia Pahang for the financial support by sponsoring this paper to be presented in the FGIC $2^{\text {nd }}$ Conference on Governance and Integrity 2019.

\section{Appendix A: Measurement ltems}

\begin{tabular}{|c|c|c|c|c|c|c|}
\hline Construct & Code & Item & Literature Support & $\begin{array}{l}\text { Outer } \\
\text { loading }\end{array}$ & AVE & $\mathrm{CR}$ \\
\hline \multirow[t]{5}{*}{$\mathrm{BINQ}$} & BIQ1 & $\begin{array}{l}\text { In general, our employees } \\
\text { have high-quality } \\
\text { awareness }\end{array}$ & $\begin{array}{l}\text { Ahlstrom (2004); } \\
\text { Malmbrandt and } \\
\text { Åhlström (2013) }\end{array}$ & 0.850 & 0.704 & 0.922 \\
\hline & BIQ2 & $\begin{array}{l}\text { We implement methods of } \\
\text { assuring quality in work } \\
\text { without having to control. }\end{array}$ & & 0.722 & & \\
\hline & BIQ3 & $\begin{array}{l}\text { Most areas are actively } \\
\text { working to ensure built-in } \\
\text { quality. }\end{array}$ & & 0.921 & & \\
\hline & BIQ4 & $\begin{array}{l}\text { Employees control quality } \\
\text { themselves before finishing } \\
\text { a job. }\end{array}$ & & 0.846 & & \\
\hline & BIQ5 & $\begin{array}{l}\text { Work tasks have been } \\
\text { specifically designed to } \\
\text { assure that quality is built-in }\end{array}$ & & 0.844 & & \\
\hline \multirow[t]{4}{*}{ LBW } & BW1 & $\begin{array}{l}\text { We have proactive } \\
\text { planning to balance } \\
\text { workloads among the } \\
\text { employees }\end{array}$ & $\begin{array}{l}\text { Apte and Goh } \\
\text { (2004); } \\
\text { Malmbrandt and } \\
\text { Åhlström (2013) }\end{array}$ & 0.895 & 0.681 & 0.892 \\
\hline & BW2 & $\begin{array}{l}\text { Our employees' workloads } \\
\text { are relatively fixed from } \\
\text { time to time. }\end{array}$ & & 0.932 & & \\
\hline & BW3 & $\begin{array}{l}\text { We emphasize a more } \\
\text { accurate forecast to avoid } \\
\text { overload in activities }\end{array}$ & & 0.866 & & \\
\hline & BW4 & $\begin{array}{l}\text { We emphasize to equate } \\
\text { workloads on each } \\
\text { employee }\end{array}$ & & 0.551 & & \\
\hline \multirow[t]{3}{*}{ CIMP } & $\mathrm{Cl} 1$ & $\begin{array}{l}\text { All employees actively } \\
\text { participate in process } \\
\text { improvement where they } \\
\text { are part of }\end{array}$ & $\begin{array}{l}\text { Malmbrandt and } \\
\text { Åhlström (2013); } \\
\text { Womack et al. } \\
\text { (1990) }\end{array}$ & 0.902 & 0.850 & 0.958 \\
\hline & $\mathrm{Cl} 2$ & $\begin{array}{l}\text { Continuous improvement is } \\
\text { part of everyday work for } \\
\text { all employees }\end{array}$ & & 0.938 & & \\
\hline & $\mathrm{Cl} 3$ & $\begin{array}{l}\text { Employees are proficient in } \\
\text { problem-solving } \\
\text { techniques for continuous } \\
\text { improvement }\end{array}$ & & 0.925 & & \\
\hline
\end{tabular}




\begin{tabular}{|c|c|c|c|c|c|c|}
\hline \multirow[t]{2}{*}{ Construct } & Code & Item & Literature Support & $\begin{array}{l}\text { Outer } \\
\text { loading }\end{array}$ & AVE & CR \\
\hline & $\mathrm{Cl} 4$ & $\begin{array}{l}\text { We have clear focuses for } \\
\text { continuous improvement }\end{array}$ & & 0.921 & & \\
\hline \multirow[t]{4}{*}{ MFE } & ME1 & $\begin{array}{l}\text { If an employee has } \\
\text { no/fewer jobs, she/he can } \\
\text { do other works within the } \\
\text { same department/division }\end{array}$ & $\begin{array}{l}\text { Bowen and } \\
\text { Youngdahl (1998); } \\
\text { Malmbrandt and } \\
\text { Åhlström (2013) }\end{array}$ & 0.716 & 0.660 & 0.885 \\
\hline & ME2 & $\begin{array}{l}\text { If one employee is absent, } \\
\text { another employee can take } \\
\text { the same responsibilities }\end{array}$ & & 0.764 & & \\
\hline & ME3 & $\begin{array}{l}\text { Our employees are } \\
\text { capable of performing } \\
\text { several different jobs }\end{array}$ & & 0.912 & & \\
\hline & ME4 & $\begin{array}{l}\text { Our staff are cross-trained } \\
\text { in order to be able to } \\
\text { perform several different } \\
\text { jobs }\end{array}$ & & 0.843 & & \\
\hline \multirow[t]{5}{*}{ PULL } & PS1 & $\begin{array}{l}\text { Most of the operations in } \\
\text { our university are } \\
\text { performed based upon } \\
\text { specific needs }\end{array}$ & $\begin{array}{l}\text { Malmbrandt and } \\
\text { Åhlström (2013); } \\
\text { Radnor (2010) }\end{array}$ & 0.819 & 0.821 & 0.958 \\
\hline & PS2 & $\begin{array}{l}\text { We do a particular job as } \\
\text { necessary, no more and no } \\
\text { less }\end{array}$ & & 0.956 & & \\
\hline & PS3 & $\begin{array}{l}\text { Each step in the chain of } \\
\text { processes is aware of the } \\
\text { status of the previous and } \\
\text { next step of the operations }\end{array}$ & & 0.946 & & \\
\hline & PS4 & $\begin{array}{l}\text { Each step has a signal for } \\
\text { when to start working }\end{array}$ & & 0.962 & & \\
\hline & PS5 & $\begin{array}{l}\text { We do a particular job only } \\
\text { when requested for by its } \\
\text { users }\end{array}$ & & 0.838 & & \\
\hline \multirow[t]{5}{*}{ WID } & WI1 & $\begin{array}{l}\text { We conducted value } \\
\text { stream mapping to identify } \\
\text { non-value-added activities } \\
\text { at our university }\end{array}$ & $\begin{array}{l}\text { Malmbrandt and } \\
\text { Åhlström (2013); } \\
\text { Stentoft Arlbjørn, } \\
\text { Vagn Freytag, and } \\
\text { de Haas (2011) }\end{array}$ & 0.915 & 0.830 & 0.961 \\
\hline & WI2 & $\begin{array}{l}\text { Non-value-added activities } \\
\text { are identified based on } \\
\text { recurring internal problems }\end{array}$ & & 0.891 & & \\
\hline & WI3 & $\begin{array}{l}\text { Non-value-added activities } \\
\text { are identified based on the } \\
\text { customer perspective }\end{array}$ & & 0.941 & & \\
\hline & W14 & $\begin{array}{l}\text { Process maps are } \\
\text { visualized in the workplace }\end{array}$ & & 0.910 & & \\
\hline & WI5 & $\begin{array}{l}\text { Process maps are updated } \\
\text { regularly }\end{array}$ & & 0.898 & & \\
\hline WSTD & WS1 & $\begin{array}{l}\text { We use formal work } \\
\text { standards in most of the } \\
\text { work areas }\end{array}$ & $\begin{array}{l}\text { Malmbrandt and } \\
\text { Åhlström (2013); } \\
\text { Papadopoulos, } \\
\text { Radnor, and } \\
\text { Merali (2011) }\end{array}$ & 0.913 & 0.829 & 0.951 \\
\hline
\end{tabular}




\begin{tabular}{|c|c|c|c|c|c|c|}
\hline \multirow[t]{4}{*}{ Construct } & Code & Item & Literature Support & $\begin{array}{l}\text { Outer } \\
\text { loading }\end{array}$ & AVE & CR \\
\hline & WS2 & $\begin{array}{l}\text { We have explicit, detailed } \\
\text { and written standards for } \\
\text { most of the jobs }\end{array}$ & & 0.887 & & \\
\hline & WS3 & $\begin{array}{l}\text { Our work standards are } \\
\text { continuously challenged } \\
\text { and updated }\end{array}$ & & 0.915 & & \\
\hline & WS4 & $\begin{array}{l}\text { We standardize the works } \\
\text { to reduce works' } \\
\text { processing times }\end{array}$ & & 0.928 & & \\
\hline \multirow[t]{4}{*}{ ECSP } & ECSP1 & $\begin{array}{l}\text { Overall return on } \\
\text { investment has increased }\end{array}$ & $\begin{array}{l}\text { Aleixo et al. } \\
\text { (2018a); Lozano } \\
\text { et al. (2015) }\end{array}$ & 0.937 & 0.843 & 0.955 \\
\hline & ECSP2 & $\begin{array}{l}\text { Energy efficiency has } \\
\text { increased }\end{array}$ & & 0.936 & & \\
\hline & ECSP3 & $\begin{array}{l}\text { Operational costs of our } \\
\text { university have reduced }\end{array}$ & & 0.899 & & \\
\hline & ECSP4 & $\begin{array}{l}\text { Overall financial } \\
\text { performance of our } \\
\text { university has been } \\
\text { outstanding }\end{array}$ & & 0.898 & & \\
\hline \multirow[t]{5}{*}{ ENSP } & ENSP1 & $\begin{array}{l}\text { Water consumption has } \\
\text { significantly reduced }\end{array}$ & $\begin{array}{l}\text { Aleixo et al. } \\
\text { (2018a); Lozano } \\
\text { et al. (2015) }\end{array}$ & 0.801 & 0.753 & 0.938 \\
\hline & ENSP2 & $\begin{array}{l}\text { The use of electricity has } \\
\text { significantly reduced }\end{array}$ & & 0.892 & & \\
\hline & ENSP3 & $\begin{array}{l}\text { Total fuel consumption } \\
\text { used in transportation has } \\
\text { significantly reduced }\end{array}$ & & 0.896 & & \\
\hline & ENSP4 & $\begin{array}{l}\text { Solid waste disposals have } \\
\text { significantly reduced }\end{array}$ & & 0.915 & & \\
\hline & ENSP5 & $\begin{array}{l}\text { The number of energy } \\
\text { efficient equipment has } \\
\text { increased }\end{array}$ & & 0.830 & & \\
\hline \multirow[t]{5}{*}{ ISP } & ISP1 & $\begin{array}{l}\text { The number of researches } \\
\text { to promote campus } \\
\text { sustainability has increased }\end{array}$ & $\begin{array}{l}\text { Aleixo et al. } \\
\text { (2018a); Lozano } \\
(2011)\end{array}$ & 0.907 & 0.808 & 0.955 \\
\hline & ISP2 & $\begin{array}{l}\text { Level of stakeholders' } \\
\text { understanding of the } \\
\text { sustainability issues has } \\
\text { increased }\end{array}$ & & 0.893 & & \\
\hline & ISP3 & $\begin{array}{l}\text { The number of R \& D } \\
\text { projects on university's } \\
\text { sustainable development } \\
\text { has increased }\end{array}$ & & 0.928 & & \\
\hline & ISP4 & $\begin{array}{l}\text { Participations of our staff in } \\
\text { on-campus sustainable } \\
\text { development activities } \\
\text { have increased }\end{array}$ & & 0.856 & & \\
\hline & ISP5 & $\begin{array}{l}\text { Overall institutional } \\
\text { sustainability performance } \\
\text { of our university has been } \\
\text { outstanding }\end{array}$ & & 0.908 & & \\
\hline
\end{tabular}




\begin{tabular}{|c|c|c|c|c|c|c|}
\hline Construct & Code & Item & Literature Support & $\begin{array}{l}\text { Outer } \\
\text { loading }\end{array}$ & AVE & $\mathrm{CR}$ \\
\hline \multirow[t]{5}{*}{ SSP } & SSP1 & $\begin{array}{l}\text { Practices of human } \\
\text { resource management in } \\
\text { our university have been } \\
\text { outstanding }\end{array}$ & $\begin{array}{l}\text { Aleixo et al. } \\
\text { (2018a); Lozano } \\
\text { (2011) }\end{array}$ & 0.866 & 0.772 & 0.944 \\
\hline & SSP2 & $\begin{array}{l}\text { Student residence services } \\
\text { have been outstanding }\end{array}$ & & 0.902 & & \\
\hline & SSP3 & $\begin{array}{l}\text { Our occupational health } \\
\text { service has been } \\
\text { outstanding }\end{array}$ & & 0.900 & & \\
\hline & SSP4 & $\begin{array}{l}\text { Recreational, cultural or } \\
\text { sports activities (e.g., sports } \\
\text { events) were done more } \\
\text { frequent }\end{array}$ & & 0.853 & & \\
\hline & SSP5 & $\begin{array}{l}\text { Corporate social } \\
\text { responsibility (CSR)-related } \\
\text { activities have done } \\
\text { frequently }\end{array}$ & & 0.872 & & \\
\hline
\end{tabular}

\section{References}

[1] Abd-Razak, M., Abdullah, N. A. G., Nor, M. F. I. M., Usman, I. M., \& Che-Ani, A. I. (2011). Toward a sustainable campus: Comparison of the physical development planning of research university campuses in Malaysia. Journal of Sustainable Development, 4(4), 210.

[2] Abd-Razak, M., Mustafa, N., Che-Ani, A., Abdullah, N., \& Mohd-Nor, M. (2011). Campus sustainability: Student's perception on campus physical development planning in Malaysia. Procedia Engineering, 20, 230-237.

[3] Abdullah, A. H., Razman, R., \& Muslim, R. (2017). A Review on Critical Success Factors of Governance towards Sustainable Campus Operations (Vol. 226).

[4] Ahlstrom, P. (2004). Lean service operations: translating lean production principles to service operations. International Journal of Services Technology and Management, 5(5-6), 545-564.

[5] Aleixo, Ulisses, A., \& Susana, L. (2018a). The implementation of sustainability practices in Portuguese higher education institutions. International Journal of Sustainability in Higher Education, 19(1), 146-178. doi: doi:10.1108/IJSHE-02-2017-0016

[6] Aleixo, A. M., Azeiteiro, U., \& Leal, S. (2018b). The implementation of sustainability practices in portuguese higher education institutions. International Journal of Sustainability in Higher Education(just-accepted), 00-00.

[7] Amaral Luís, Martins Nelson, \& Gouveia Joaquim. (2015). Quest for a sustainable university: a review. International Journal of Sustainability in Higher Education, 16(2), 155-172. doi: doi:10.1108/IJSHE-02-2013-0017 
[8] Apte, U. M., \& Goh, C.-H. (2004). Applying lean manufacturing principles to information intensive services. International journal of services technology and management, 5(5-6), 488-506.

[9] Balzer, W. K., Brodke, M. H., \& Thomas Kizhakethalackal, E. (2015). Lean higher education: successes, challenges, and realizing potential. International Journal of Quality \& Reliability Management, 32(9), 924-933.

[10] Bowen, D. E., \& Youngdahl, W. E. (1998). "Lean" service: in defense of a productionline approach. International journal of service industry management, 9(3), 207-225.

[11] Cathryn, H., \& Deborah, C. (2008). Sustaining academic life: A case for applying principles of social sustainability to the academic profession. International Journal of Sustainability in Higher Education, 9(3), 235-245. doi: doi:10.1108/14676370810885862

[12] Cebrián, G., Grace, M., \& Humphris, D. (2015). Academic staff engagement in education for sustainable development. Journal of Cleaner Production, 106, 79-86.

[13] Clare, \& Dennis. (2005b). A case study in applying lean sustainability concepts to universities. International Journal of Sustainability in Higher Education, 6(2), 134-146. doi: doi:10.1108/14676370510589855

[14] Cudney, E. A., Venuthurumilli, S. S. J., Materla, T., \& Antony, J. (2018). Systematic review of Lean and Six Sigma approaches in higher education. Total Quality Management \& Business Excellence, 1-14.

[15] Darus, Z. M., Khalim, A., Rashid, K., Hashim, N. A., Omar, M. Z., Saruwono, M., \& Mohammad, N. (2009). Development of Sustainable Campus: Universiti Kebangsaan Malaysia Planning and Strategy (Vol. 5).

[16] Dinis-Carvalho, J., \& Fernandes, S. (2017). Applying Lean Concepts to Teaching and Learning in Higher Education: Findings from a Pilot Study. International Journal of Engineering Education, 33(3), 1048-1059.

[17] Doman Mark. (2011). A new lean paradigm in higher education: a case study. Quality Assurance in Education, 19(3), 248-262. doi: doi:10.1108/09684881111158054

[18] Douglas, J., Antony, J., \& Douglas, A. (2015). Waste identification and elimination in HEls: the role of Lean thinking. International Journal of Quality \& Reliability Management, 32(9), 970-981.

[19] Dyer, G., \& Dyer, M. (2017). Strategic leadership for sustainability by higher education: the American College \& University Presidents' Climate Commitment. Journal of Cleaner Production, 140, 111-116.

[20] Fischer, D., Jenssen, S., \& Tappeser, V. (2015). Getting an empirical hold of the sustainable university: a comparative analysis of evaluation frameworks across 12 
contemporary sustainability assessment tools. Assessment \& Evaluation in Higher Education, 4O(6), 785-800. doi: 10.1080/02602938.2015.1043234

[21] Florida, R. (1996). Lean and Green: The Move to Environmentally Conscious Manufacturing. California Management Review, 39(1), 80-105. doi: 10.2307/41165877

[22] Furlan, A., Vinelli, A., \& Dal Pont, G. (2011). Complementarity and lean manufacturing bundles: an empirical analysis. International Journal of Operations \& Production Management, 31(8), 835-850. doi: 10.1108/01443571111153067

[23] Godemann, J., Bebbington, J., Herzig, C., \& Moon, J. (2014). Higher education and sustainable development: Exploring possibilities for organisational change. Accounting, Auditing \& Accountability Journal, 27(2), 218-233.

[24] Gold, A. H., Malhotra, A., \& Segars, A. H. (2001). Knowledge management: An organizational capabilities perspective. Journal of management information systems, 18(1), 185-214.

[25] Government of Malaysia. (2017). Malaysia sustainable Development Goals voluntary national review

[26] Hadid, W., \& Mansouri, S. A. (2014). The lean-performance relationship in services: A theoretical model. International Journal of Operations \& Production Management, 34(6), 750-785. doi: 10.1108/IJOPM-02-2013-0080

[27] Hair, J. F., Hult, G. T. M., Ringle, C., \& Sarstedt, M. (2017). A primer on partial least squares structural equation modeling (PLS-SEM) (2nd ed.). Los Angeles: Sage Publications.

[28] Hair Jr, J. F., Hult, G. T. M., Ringle, C., \& Sarstedt, M. (2016). A primer on partial least squares structural equation modeling (PLS-SEM): Sage Publications.

[29] Henao, R., Sarache, W., \& Gómez, I. (2018). Lean Manufacturing and Sustainable Performance: trends and future challenges. Journal of cleaner production.

[30] Hines, P., Found, P., Griffiths, G., \& Harrison, R. (2011). Staying Lean: thriving, not just surviving: Productivity Press.

[31] Hussain, M., Al-Aomar, R., \& Melhem, H. (2019). Assessment of lean-green practices on the sustainable performance of hotel supply chains. International Journal of Contemporary Hospitality Management.

[32] Hussin, R., \& Kunjuraman, V. (2017). Exploring strategies for sustainable 'ecocampus': The experience of Universiti Malaysia Sabah. Geografia-Malaysian Journal of Society and Space, 11(3).

[33] lacobucci, D., Saldanha, N., \& Deng, X. (2007). A meditation on mediation: Evidence that structural equations models perform better than regressions. Journal of Consumer Psychology, 17(2), 139-153. 
[34] Iranmanesh, M., Zailani, S., Hyun, S. S., Ali, M. H., \& Kim, K. (2019). Impact of Lean Manufacturing Practices on Firms' Sustainable Performance: Lean Culture as a Moderator. Sustainability, 11(4), 1112.

[35] Khanchanapong, T., Prajogo, D., Sohal, A. S., Cooper, B. K., Yeung, A. C. L., \& Cheng, T. C. E. (2014). The unique and complementary effects of manufacturing technologies and lean practices on manufacturing operational performance. International Journal of Production Economics, 153, 191-203. doi: 10.1016/j.jpe.2014.02.021

[36] King, A. A., \& Lenox, M. J. (2001). Lean and green? An empirical examination of the relationship between lean production and environmental performance. Production and operations management, 10(3), 244-256.

[37] Kwami, H., Che-Ani, A., Tawil, N., Tahir, M., \& Basri, H. (2014). Approach to Campus Sustainability at Universiti Kebangsaan Malaysia (UKM): A Review. Paper presented at the E3S Web of Conferences.

[38] Latan, H., Jabbour, C. J. C., de Sousa Jabbour, A. B. L., Renwick, D. W. S., Wamba, S. F., \& Shahbaz, M. (2018). 'Too-much-of-a-good-thing'? The role of advanced eco-learning and contingency factors on the relationship between corporate environmental and financial performance. Journal of environmental management, 220, 163-172.

[39] Leal Filho, W., Brandli, L. L., Becker, D., Skanavis, C., Kounani, A., Sardi, C.,... de Sousa, L. O. (2018). Sustainable Development Policies as Indicators and Pre-Conditions for Sustainability Efforts at Universities: fact or fiction? International Journal of Sustainability in Higher Education(just-accepted), 00-00.

[40] Low, S. T., Abdul, H. B. M., \& Weng, W. C. (2012). Proposed implementation strategies for energy sustainability on a Malaysian university campus. Business Strategy Series, 13(5), 208-214. doi: doi:10.1108/17515631211264087

[41] Lozano, R. (2011). The state of sustainability reporting in universities. International Journal of Sustainability in Higher Education, 12(1), 67-78.

[42] Lozano, R., Ceulemans, K., Alonso-Almeida, M., Huisingh, D., Lozano, F. J., Waas, T.,... Hugé, J. (2015). A review of commitment and implementation of sustainable development in higher education: results from a worldwide survey. Journal of Cleaner Production, 108, 1-18. doi: https://doi.org/10.1016/j.jclepro.2014.09.048

[43] Malmbrandt, M., \& Åhlström, P. (2013). An instrument for assessing lean service adoption. International Journal of Operations \& Production Management, 33(9), 1131 1165.

[44] Martínez-Jurado, P. J., \& Moyano-Fuentes, J. (2014). Lean management, supply chain management and sustainability: a literature review. Journal of Cleaner Production, 
85, 134-150.

[45] Mason-Jones, R., Naylor, B., \& Towill, D. R. (2000). Lean, agile or leagile? Matching your supply chain to the marketplace. International Journal of Production Research, 38(17), 4061-4070.

[46] Ministry of Education Malaysia. (2015). Malaysia Education Blueprint 2015-2025 (Higher Education). Putrajaya: Ministry of Education Malaysia.

[47] Montgomery, D. (2017). Lean six-sigma in higher education. Quality and Reliability Engineering International, 33(5), 935-936.

[48] Moreira, F., Alves, A. C., \& Sousa, R. M. (2010). Towards Eco-efficient Lean Production Systems, Berlin, Heidelberg.

[49] Moyano-Fuentes, J., \& Sacristán-Díaz, M. (2012). Learning on lean: a review of thinking and research. International Journal of Operations \& Production Management, 32(5), 551-582. doi: doi:10.1108/01443571211226498

[50] Narayanamurthy, G., Gurumurthy, A., \& Chockalingam, R. (2017). Applying lean thinking in an educational institute-an action research. International Journal of Productivity and Performance Management, 66(5), 598-629.

[51] Nawanir, G., Lim, K. T., Othman, S. N., \& Adeleke, A. Q. (2018). Developing and validating lean manufacturing constructs: an SEM approach. Benchmarking: An International Journal, 25(5), 1382-1405. doi: doi:10.1108/BIJ-02-2017-0029

[52] Papadopoulos, T., Radnor, Z., \& Merali, Y. (2011). The role of actor associations in understanding the implementation of Lean thinking in healthcare. International Journal of Operations \& Production Management, 31(2), 167-191.

[53] Pfahl, S. (2005). Institutional sustainability. International journal of sustainable development, 8(1-2), 80-96.

[54] Phan, C. A., \& Matsui, Y. (2010). Comparative study on the relationship between justin-time production practices and operational performance in manufacturing plants. Operations Management Research, 3, 184-198. doi: 10.1007/s12063-010-0040-4

[55] Piercy, N., \& Rich, N. (2015). The relationship between lean operations and sustainable operations. International Journal of Operations \& Production Management, 35(2), 282-315.

[56] Preacher, K. J., \& Kelley, K. (2011). Effect size measures for mediation models: Quantitative strategies for communicating indirect effects. Psychological Methods, 16(2), 93-115. doi: 10.1037/a0022658

[57] Radnor, Z. (2010). Transferring Lean into government. Journal of Manufacturing Technology Management, 21(3), 411-428. 
[58] Scott, R. H. (2009). Environmental and social sustainability impacts of teaching and research: some ideas. eCULTURE, 2(1), 19.

[59] Stentoft Arlbjørn, J., Vagn Freytag, P., \& de Haas, H. (2011). Service supply chain management: A survey of lean application in the municipal sector. International Journal of Physical Distribution \& Logistics Management, 41(3), 277-295.

[60] Thomas, A., Antony, J., Francis, M., \& Fisher, R. (2015). A comparative study of Lean implementation in higher and further education institutions in the UK. International Journal of Quality \& Reliability Management, 32(9), 982-996.

[61] Vamsi Krishna Jasti, N., \& Kodali, R. (2014). A literature review of empirical research methodology in lean manufacturing. International Journal of Operations \& Production Management, 34(8), 1080-1122.

[62] Womack, J. P., Jones, D. T., \& Roos, D. (1990). Machine that Changed the World: Scribner.

[63] Zen, I. S., \& LatifSaleh, M. B. R. Z. A. (2013). The UTM Sustainable Campus: Institutionalize Sustainability, The Living Lab Approach and Sustainable Energy Management Program. Paper presented at the International Workshop on UI Greenmatric. 